\title{
Awareness of Osteoporosis among Females, Eastern Province, KSA
}

\author{
Mohammed Alhassan ${ }^{1}$, Lina Alyousif ${ }^{2}$, Mustafa Al-Battat $^{3}$, Abdullah Alhassan ${ }^{4}$, Sarah Alshukr $^{5}$, \\ Muaath Al Ghamdi ${ }^{6}$
}

\begin{abstract}
Introduction: The osteoporosis is a progressive systemic skeletal disease characterized by low bone mass and microarchitectural deterioration of bone tissue, with a consequent increase in bone fragility and susceptibility to fracture linked with excess morbidity and mortality. It is a serious silent disease that develops slowly over so many years and often diagnosed after the fragility fracture happened. The incidence of vertebral fractures due to osteoporosis in KSA is between $20 \%-24 \%{ }^{2}$. Materials and Methods: The study is based on an electronic questionnaire which carried out in eastern province during October to November 2016. The targeted group was 250 females. The subjects participating in the study were chosen at random from urban and suburban communities. Results: A total of 250 subjects completed the questionnaire. The age response of subjects as following less than 45 (86.64\%), from 45 to 55 (10.53\%), more than $55(2.83 \%)$. Out of them $58.4 \%$ of participants were premenopausal and $41.6 \%$ were postmenopausal. Conclusions: Our study demonstrated that women in eastern province, Saudi Arabia is not fully aware about osteoporosis. The findings demonstrate that awareness and education are important factors in maintaining healthy bones among them.
\end{abstract}

Keywords: osteoporosis, osteoporosis risk factor, premenopausal women, menopausal women, Saudi women

\section{Introduction}

The osteoporosis is a progressive systemic skeletal disease characterized by low bone mass and micro-architectural deterioration of bone tissue, with a consequent increase in bone fragility and susceptibility to fracture linked with excess morbidity and mortality. Osteoporosis affects both sexes. The World Health Organization (WHO) defined osteoporosis as "an epidemic of the 21 century" [1].Osteoporosis prevalence in the Kingdom of Saudi Arabia (KSA) is about $34 \%$ in healthy Saudi women aged between $50-79$ years, and $30.7 \%$ in men [2]. The incidence of vertebral fractures due to osteoporosis in KSA is between $20 \%-24 \%$ [2]. Osteoporosis has become an increasing health problem. It is a serious silent disease that develops slowly over so many years and often diagnosed after the fragility fracture happened. The incidence of vertebral fractures due to osteoporosis in KSA is between $20 \%-24 \%$ [2]. In Italy, 90000 hip fractures per year affect persons aged older than 50 years [3]. Developing this disease depends on many factors like genetic predisposition, aging, dietary habits, physical activity, endocrine changes, lifestyles, general health condition and using medications [4]. The good thing is that osteoporosis easily recognized by screening suspected subjects (the recommended age for screening healthy subjects is at age of 65 years) [5]. The most dominant risk factors in society include postmenopausal age, diet (shortage of calcium intake) and lack of regular exercise $[6,7]$. Unfortunately, osteoporosis receives a low level of attention in primary health-care programs in most underdeveloped countries, where most women are largely unaware of the serious complications associated with osteoporosis. Minimizing the risk of acquiring the disease begins by modification of individuals' life-style to combat related risk factors and identification of patients at high risk to reduce the likelihood of fractures in the future. Life-style modification includes avoidance of alcohol consumption and cigarette smoking, and ensuring a high-quality and balanced diet, regular exercise, and adequate calcium and vitamin D intake (dietary or via supplements). Daily skin exposure to sun light for more than 15 minutes is also highly recommended $[8,9]$.We believe that improving the knowledge and the awareness of the women in eastern province of Saudi Arabia about osteoporosis will had a positive impaction in bone health and future fractures protections. So, the present study will carry out to investigate and assess the awareness of osteoporosis among Saudi women in eastern province. Eventually, the extended objective of our work is to evaluate the seriousness of osteoporosis in the society in comparison to the populations of neighboring and other countries.Aim: assessment of awareness level of osteoporosis among females. At the same time, we will assess the risk and protective factors of osteoporosis among women in eastern province, Saudi Arabia.

\section{Materials and Methods}

The study is based on an electronic questionnaire which carried out in eastern province during October to November 2016. The targeted group was 250females. The subjects participating in the study were chosen at random from urban and suburban communities. The predesigned questionnaire consisted of 29 questions including 2 multiple choices, 21 single choice and 6 were open-ended questions. The questionnaire asked respondents about their age, age at menarche, age at menopause, weight,hight, education level, socioeconomic status, community, children number, years of lactation, and their knowledge on osteoporosis issues that included previous fractures, treatment, risk and protective factors, family history, prevention, screening age as well as the relationship of osteoporosis with the consumed milk and dairy products, soft drink, physical activity. Table 2

Table 1: Age of study subjects

\begin{tabular}{|c|c|c|}
\hline Age & No. of subjects & Response \\
\hline Less than 45 & 214 & $86.64 \%$ \\
\hline 45 to 55 & 26 & $10.53 \%$ \\
\hline More than 55 & 7 & $2.83 \%$ \\
\hline
\end{tabular}

\section{Volume 6 Issue 1, January 2017




\section{International Journal of Science and Research (IJSR) ISSN (Online): 2319-7064}

Index Copernicus Value (2015): 78.96 | Impact Factor (2015): 6.391

Table 2: General description of study subjects

\begin{tabular}{|c|c|c|c|}
\hline Characteristic & No. of subjects & Mean & $\begin{array}{c}\text { Standard } \\
\text { deviation }\end{array}$ \\
\hline Age & & 1.16 & 0.44 \\
\hline Age at menarche & 241 & 12.64583 & 1.741825 \\
\hline Weight & 239 & 63.28059 & 16.7114 \\
\hline Height & 229 & 155.1801 & 22.02639 \\
\hline BMI & 228 & 26.0813 & 14.42939481 \\
\hline No. of children & 177 & 3.646259 & 2.403665 \\
\hline Years of lactation & 168 & 3.106618 & 3.039592 \\
\hline Age at menopause & 104 & 49.5 & 23.72089 \\
\hline
\end{tabular}

\section{Result}

A total of 250 subjects completed the questionnaire. The age response of subjects as following less than 45 (86.64\%), from 45 to $55(10.53 \%)$, more than $55(2.83 \%)$, Table 1 . Out of them $58.4 \%$ of participants were premenopausal and 41.6 $\%$ were postmenopausal. That we can calculate their Body Mass Index (BMI). We found that the mean BMI measurement was $26 \mathrm{~kg} / \mathrm{m} 2$. The education level of the subjects is shown in Table 3.

Table 3: The education level of the subjects according to menopausal status

\begin{tabular}{|c|c|c|c|c|}
\hline & $\begin{array}{c}\text { Pre- } \\
\text { Menopausa }\end{array}$ & $\begin{array}{c}\text { Post- } \\
\text { menopausal }\end{array}$ & & \\
\hline Education level & $\%$ & $\%$ & Total count & Total \% \\
\hline Primary & $1.21 \%$ & $0.808 \%$ & 5 & $2.02 \%$ \\
\hline Intermediate & $1.21 \%$ & $1.21 \%$ & 6 & $2.42 \%$ \\
\hline Secondary & $22.58 \%$ & $3.22 \%$ & 64 & $25.81 \%$ \\
\hline Academic & $56.04 \%$ & 8.871 & 161 & $64.92 \%$ \\
\hline Master & $1.61 \%$ & & 4 & $1.61 \%$ \\
\hline Ph.D. & $1.21 \%$ & & 3 & $1.2 \%$ \\
\hline Otherwise & $1.616 \%$ & 0.404 & 5 & $2.02 \%$ \\
\hline
\end{tabular}

Women after menopause are more likely to suffer from osteoporosis by $76.42 \%$. $59.26 \%$ disagreed about menopause at an early age is not dangerous for osteoporosis. Around $36.33 \%$ they thought the loss of bone density occur without the presence of physical symptoms. Most of the subjects $92.71 \%$ agreed about bone examination after menopause is very important to see the possibility of interruption diagnosed with osteoporosis.Participants were asked if they got fractures previously. About $84.21 \%$ they said no, whereas $15.79 \%$ said yes then asked about the site of fractures. The result as following; Spin0.00\%, Femur $3.92 \%$, Pelvis $0.00 \%$, others $96.08 \%$. regarding to the association of previous fractures and likelihood of osteoporosis, most of them $60.66 \%$ agrees there is no association.About $77.31 \%$ of the participants thought there is cure for osteoporosis and around $22.69 \%$ they didn't think that.Regarding the important of estrogen in maintaining of bone health most of the participant said yes $(87.55 \%)$, while the rest $(12.45 \%)$ believes no role of estrogen at all.When we asked about 2 sources of calcium or more do they know,most of them $94.74 \%$ answered by yes, $5.26 \%$ answered no. About $91.87 \%$ of the subjects believed that osteoporosis is preventable disease and can by since childhood.
Table 4: Awareness of study subjects about various risk factors for osteoporosis

\begin{tabular}{|c|c|c|c|}
\hline Variable & Correct & Yes & No \\
\cline { 3 - 4 } answer & $\%$ & $\%$ \\
\hline $\begin{array}{c}\text { Postmenopausal women more } \\
\text { susceptible to osteoporosis }\end{array}$ & Yes & $76.42 \%$ & $23.58 \%$ \\
\hline $\begin{array}{c}\text { Surgical removal of ovaries } \\
\text { decreases the likelihood of } \\
\text { developing osteoporosis }\end{array}$ & No & $11.54 \%$ & $88.46 \%$ \\
\hline $\begin{array}{c}\text { Previous fractures have no } \\
\text { effect on developing osteoporosis }\end{array}$ & No & $60.66 \%$ & $39.34 \%$ \\
\hline $\begin{array}{c}\text { Family history has no effect } \\
\text { on developing osteoporosis }\end{array}$ & No & $34.41 \%$ & $65.59 \%$ \\
\hline $\begin{array}{c}\text { Inadequate calcium intake } \\
\text { contributes to the development } \\
\text { of osteoporosis }\end{array}$ & Yes & $90.32 \%$ & $9.68 \%$ \\
\hline $\begin{array}{c}\text { Caffeine-containing beverages } \\
\text { (coffee, tea, soft drinks such as } \\
\text { cola) }\end{array}$ & Yes & $88.76 \%$ & $11.24 \%$ \\
$\begin{array}{c}\text { increase the likelihood of } \\
\text { developing osteoporosis }\end{array}$ & & & \\
\hline $\begin{array}{c}\text { Smoking tobacco has no effect } \\
\text { on developing osteoporosis }\end{array}$ & No & 17.6 & 59.2 \\
\hline $\begin{array}{c}\text { Menopause at an early age } \\
\text { is not dangerous for osteoporosis }\end{array}$ & No & $40.74 \%$ & $59.26 \%$ \\
\hline
\end{tabular}

Concerning food supplements and therapy, only about $36.46 \%$ of the subjects were taking calcium supplement and about $36.46 \%$ were taking vitamin D supplement. Only $23.76 \%$ of subjects were taking daily multivitamins and $2.76 \%$ were on estrogen replacement therapy. The majority of the subjects $58.4 \%$ were premenopausal and $41.6 \%$ were postmenopausal and $65.59 \%$ of the subjects believed on family history of osteoporosis is one of the risk factor. Most subjects responded correctly when asked about the effect of specific risk factors including caffeine, soft drinks (about $88.76 \%$ ) and low calcium food (about 90.32\%)Table 4. About $78.23 \%$ of subjects were aware that exercise such as walking helps to increase bone density. In otherward, limiting movement reduces bone remodeling resulting in weak bones. About $88.46 \%$ of subjects were aware that ovariectomy is a risk factor, and about $11.54 \%$ thought ovariectomy will reduce the risk of developing osteoporosis. Table 5

Table 5: Awareness of study subjects about osteoporosis prevention, diagnosis and symptoms:

\begin{tabular}{|c|c|c|c|}
\hline \multirow[t]{2}{*}{ Variable } & \multirow{2}{*}{$\begin{array}{l}\text { Correct } \\
\text { answer }\end{array}$} & Yes & No \\
\hline & & $\%$ & $\%$ \\
\hline $\begin{array}{l}\text { Osteoporosis prevention } \\
\text { begins in childhood }\end{array}$ & Yes & $91.87 \%$ & $8.13 \%$ \\
\hline $\begin{array}{l}\text { Frequent exposure of the skin } \\
\text { to sun contributes to the } \\
\text { development of osteoporosis }\end{array}$ & No & $7.29 \%$ & $92.71 \%$ \\
\hline $\begin{array}{c}\text { Regular exercise such as } \\
\text { walking increases bone density }\end{array}$ & Yes & $78.23 \%$ & $21.77 \%$ \\
\hline $\begin{array}{l}\text { Bone loss in osteoporosis } \\
\text { occurs without symptoms or } \\
\text { warning signs }\end{array}$ & Yes & $36.33 \%$ & $63.67 \%$ \\
\hline $\begin{array}{l}\text { Postmenopausal women } \\
\text { should test their bones to } \\
\text { check if they are at risk of } \\
\text { developing osteoporosis }\end{array}$ & Yes & $92.71 \%$ & $7.29 \%$ \\
\hline
\end{tabular}

The awareness level of osteoporosis was significantly associated with age $(p<0.001)$, educational level $(p=0.001)$,

\section{Volume 6 Issue 1, January 2017 www.ijsr.net}




\section{International Journal of Science and Research (IJSR) \\ ISSN (Online): 2319-7064}

Index Copernicus Value (2015): 78.96 | Impact Factor (2015): 6.391

and residency $(p<0.001)$. Awareness was significantly associated with the use of dietary supplements, calcium, vitamin $\mathrm{D}$, multivitamins $(p<0.001)$. There is significant correlation between age and social status $(\mathrm{p}=<0.009)$, social status and treatment of osteoporosis $(\mathrm{P}<0.001)$, Previous fractures and knowing sources of calcium $(\mathrm{P}<0.001)$. We found that there is statistically significant positive correlation between the level of education and Caffeinecontaining beverages $(\mathrm{p}=<0.05)$, between BMI and start of menarche $(\mathrm{P}=0.01)$. The correlation between awareness of the disease with age and education level was positive. There was no correlation between subjects who had previous fractures and family history of osteoporosis $(\mathrm{P}>0.1)$

\section{Discussion}

The aim of our study to evaluate the knowledge and awareness of osteoporosis in eastern province's women in regardless to menopausal status. In our study, most of women are educated, doing exercise taking calcium and multivitamins that enhance the knowledge of osteoporosis. The awareness of risk and preventive factors is excellent. The majority know the risk and preventive factors. There is a need to increase the awareness of women in eastern province to reach the optimum level of bone health regarding osteoporosis. The unequal age distribution of our subjects limited our study in the presence of women over the age of 70 years. This limitation does not affect the main findings. The results demonstrate that tow-third of the subjects (about 59\%) were obese and about 31\% were overweight. These results show significant positive correlation between BMI and increase risk of osteoporosis. Our study represents the level of awareness about osteoporosis was significantly associated with age, education level, residency, food supplements. The findings provide good background and awareness of women in age less than 45 who are well educated and know about the disease is medium. These findings push us to raise the level of awareness about osteoporosis in society.

\section{Conclusion}

Our study demonstrated that women in eastern province, Saudi Arabia is not fully aware about osteoporosis. Our findings demonstrate that awareness and education are important factors in maintaining healthy bones among women.

\section{Acknowledgments}

We would like to thanks Mahdi Alhajji, Mohammed Albarrak, Mohammed Alrasasi, Hayder Alnofaily and Murtada Alfayez for participating in data acquisition. Especial thanks for Abdullah K. Al Bahrani for his help.

\section{Author's Contributions}

Mohammed Alhassan is the main author and participated in the study concept, literature review, study design, data analysis and manuscript preparation. Alyousif, Al-Battat,
Alhassan, Alshukr, AlGhamdi are co-author and participated in literature review and study design.

\section{References}

[1] World Health Organization. Assessment of fracture risk and its application to screening for postmenopausal osteoporosis. Report of a WHO study group. Geneva: World Health Organization; 1994.

[2] Sadat-Ali M, Al-Habdan IM, Al-Turki HA, Azam MQ. An epidemiological analysis of the incidence of osteoporosis and osteoporosis-related fractures among the Saudi Arabian population. Ann Saudi Med. 2012; 3:637-641. [PubMed].

[3] Piscitelli P, Iolascon G, Argentiero A. Incidence and costs of hip fractures vs strokes and acute myocardial infarction in Italy: comparative analysis based on national hospitalization records. Clin Interv Aging. 2012;7:575-583.

[4] Dontas IA, Yiannakopoulos CK. Risk factors and prevention of osteoporosis-related fractures. J Musculoskelet Neuronal Interact. 2007 Jul-Sep;7(3):26872.

[5] The U.S. Preventive Services Task Force. Osteoporosis: Screening. July 2015. Available from: http://www.uspreventiveservicestaskforce.org/Page/Docu ment/UpdateSummaryFinal/osteoporosisscreening?ds=1 $\& s=$ Osteoporosis.

[6] Allolio B (1999) Risk factors for hip fracture not related to bone mass and their therapeutic implications. Osteoporos Int 9 (Suppl 2):S9-S16.

[7] Coates C, Myers C, Phillips J, Pope K (1998) Osteoporosis: awareness and modification of risk factors in adolescents. Internet Journal of Health Promotion. http://rhpeo.net/ijhp-articles/1998/4/ index.htm. Accessed 6 May 2010.

[8] Bohannon A (1999) Osteoporosis and African American women. J Womens Health Gend Based Med 8(5):609613.

[9] Selby P (1999) Osteoupdate. Merck. 